Open Access

\title{
Promotion of university students' collaborative skills in open innovation environment
}

\author{
Karine Oganisjana
}

Correspondence:

karine.oganisjana@rtu.Iv

Riga Technical University, 6 Kalnciema Street, Riga LV-1048, Latvia

\begin{abstract}
It is argued that the participation in open innovation processes requires a specific set of thinking, skills and behaviours founded on the willingness and readiness to exchange, accept, encourage, cooperate and co-create based on trust and collaboration. The paper presents the results of a study conducted in Riga Technical University with 85 bachelor students within the study course "Economics of entrepreneurship" in the autumn semester of 2014. The course was organised in an open environment, in which students worked in teams for solving real life problems in order to create new products and services. They had the opportunity to act not only within the University framework realising intra-team and inter-team collaboration facilitated by teachers and invited entrepreneurs, but they were also encouraged to collaborate with specialists they needed from outside the University for the realization of their projects. The qualitative content analysis of the texts of the students' reflection revealed how highly students evaluated the potential intergenerational collaboration outside the formal University frames. However their judgements on the advantages of such openness remained mainly at the level of theoretical judgements but were not followed by corresponding behaviour.
\end{abstract}

Keywords: Open innovation, Openness to experience, University education, Learning for entrepreneurship, Open innovation environment, Students' collaborative skills, Intergenerational collaboration

\section{Introduction}

The concept of "open innovation" is defined as use of purposive inflows and outflows of knowledge to accelerate internal innovation, and expand the markets for external use of innovation (Chesbrough 2003). Open innovators have specific mind-set and disposition to co-evolve ideas, co-innovate and co-create new products and services elaborating innovation ecosystems (Chesbrough et al. 2014). They have the skills to relearn, create new ways to identify, assimilate, and utilize external knowledge, making it "digestible" (Salter et al. 2014), scouting for external ideas, shepherding external ideas through internal processes, and facilitating their exploitation in the firm (Chesbrough 2003). Open innovation requires supportive environment. It was observed that although an organisation may encourage its staff to be more open, individuals often shy away from these efforts (Salter et al. 2014). The question which arises in this regard is about how to promote individuals' openness.

(C) 2015 Oganisjana. Open Access This article is distributed under the terms of the Creative Commons Attribution 4.0 International License (http://creativecommons.org/licenses/by/4.0/), which permits unrestricted use, distribution, and reproduction in any medium, provided you give appropriate credit to the original author(s) and the source, provide a link to the Creative Commons license, and indicate if changes were made. 
Psychologists argue that openness to experience is one of the Five Factor Model of personality and describes the extent to which an individual is broad minded, imaginative, curious, and original (Barrick and Mount 1991). The research, conducted by Comings and colleagues showed that openness to experience may be conditioned by DRD4 gene (Comings et al. 1999). A decade later Scott Shane and colleagues showed that there is genetic correlation between openness and opportunity recognition which indicates that the same genetic factors influence both (Shane et al. 2010). Shane and colleagues concluded that " $62 \%$ of the covariance between openness to experience and opportunity recognition is accounted for by genetic factors, leaving $38 \%$ of the variance in opportunity recognition free to be influenced by efforts to change a person's openness to experience. This observation, of course, is consistent with the belief that personality traits, like openness to experience, are difficult to change." (Shane et al. 2010:299). Despite the low probability of success, it is not excluded that openness to experience could be evolved in students if appropriate study and work environment is created.

This research was conducted within a research project "Involvement of the society in social innovation for providing sustainable development of Latvia" as part of the National Research Program "Economic Transformation, Smart Growth, Governance and Legal Framework for the State and Society for Sustainable Development-a New Approach to the Creation of a Sustainable Learning Community (EKOSOC-LV)". One of its objectives is "to elaborate a teaching and learning methodology and materials aimed at the development of social innovation, openness to novelty, interdisciplinary creative thinking and active involvement in the solution of social problems in Latvia". Therefore the exploration of the elements and mechanisms of the study process in the University which could trigger: students' collaborative skills and openness to new experience, open mind-sets and open behaviours, readiness to solve social problems is becoming of critical importance. The solution of this educational task may play a vital role also in economics. Today social innovation economy and open innovation economy are becoming increasingly important for the growth of the global economy. Social innovation economy and open innovation economy actively interact, cooperate, nurture, support and complement each other. As argued by prof. JinHyo Joseph Yun (2015), on the one hand, social innovation economy actively provides the seed for open innovation which is a new combination between creative technology and the market in the dynamics of open innovation economy system; on the other hand, many SMEs and start-ups of the open innovation economy try to join the social innovation economy with their experience and know-how and become a major supply source of knowledge (Yun 2015). This means that social innovation and open innovation "go hand-in-hand". Therefore, also the skills and behaviours both for social innovation and open innovation should be promoted within the same context.

This paper aims to analyse the situation related to the promotion of university students' collaborative skills, which implies openness to new experience in open innovation environment while solving real life problems and creating new products and services within the study course "Economics of Entrepreneurship" delivered in Riga Technical University.

The research questions:

- How to promote university students' collaborative skills in open innovation environment?

- What do students consider to be of value in studies in open innovation environment? 
It is important to emphasize that this was the author's first attempt to introduce new teaching and learning methods and approaches in the university study practice; the students were not only to write business plans for abstract business ideas, but they had to work in groups like in real enterprises, solve real life problems and elaborate prototypes of new products and test them in life with potential customers. Therefore the focus of this research was to probe such an approach and analyse whether that can be acceptable for university studies. The findings of the research based on teachers' observations and students' reflections were to reveal whether the students collaborated to a full extent using all the opportunities of the open environment and what they valued in that.

\section{The study process in open innovation environment: theoretical stance and its practical implementation}

The methodology of the promotion of university students' collaborative skills in open innovation environment used by the author in Riga Technical University is based on two main principles:

- studies should be organised close to what takes place in a real enterprise starting from the identification or generation of new opportunities and resulting with the creation of new products and services having solved real life problems;

- students should have a number of collaboration channels both inside and outside the university for the creation of new products and services.

As argued by researchers and specialists in the field of entrepreneurship education, traditional teaching and learning methods such as lectures, literature reviews and examinations do not activate students' entrepreneurship (Gibb 2002; Hannon et al. 2005; Heinonen and Poikkijoki 2006; Sogunro 2004). They consider that the most effective way to promote students' entrepreneurship is to "push" students into entrepreneurship through the structuring of learning as an entrepreneurial process (Hannon 2006; Hjorth and Johannisson 2007; Hynes 1996; McMullan and Long 1987; Tan and Frank 2006).

In entrepreneurship education theoretical knowledge should be combined with its practical application (Hannon 2006; Heinonen 2007) and experience should be combined with formal educational activities (Timmons and Stevenson 1985). The teacher should encourage students to create theory-based activities (Fiet 2000) and promote derivation of theory from practice (Shacklock et al. 2000). Students should be able to transfer what has been learnt into current practices (Antonites and Van Vuuren 2005; Heinonen and Poikkijoki 2006; Hjorth and Johannisson 2007; Jones 2006; Rae 2007; Tan and Frank Ng 2006; Wing Yan Man 2006). This transfer can be related to their own or other people's previous experiences of success or failure of direct or indirect relevance (Wing Yan Man 2006). As for teaching interventions, they may appear in a separate and sporadic mode, but in the longer term they form more holistic and sequential learning circles in which new knowledge and activity continuously produce new experiences through individual reflection in a social context (Heinonen and Poikkijoki 2006).

The best way of learning for entrepreneurship is to learn as entrepreneurs do - learn by doing (Chesbrough 2003), reflecting (Antonites and Van Vuuren 2005; Heinonen 2007) from their mistakes based on their own experience (Hjorth and Johannisson 2007; Rae and Carswell 2000; Wing Yan Man 2006). This should cause certain changes 
in the role and mission of the teachers who are to be in dialogue with students, ready to learn together with them and from them acting as a coordinators, colleagues and facilitators (Hannon 2006; Heinonen 2007; Hynes 1996; Kearney 1999).

Entrepreneurship education comprises two principal aspects: the first one encompasses a broader view of education which is oriented to the development of students' entrepreneurial attitudes and skills but is not directly oriented to the creation of a new enterprise (Bikse 2009; Gibb 2002; Kearney 1999); the second one concerns the development of entrepreneurship competence in the educational process accompanied with the creation and management of a new enterprise (Bikse 2009) by playing entrepreneurial games (Caird 1993), attending student business clubs and regular campuses (Tan and Frank 2006) or by industrial visits and participation in a real enterprise (Antonites and Van Vuuren 2005; Erkkila 1996; Wilson 2008).

The approach analysed in this paper concerns the first aspect of entrepreneurship education. Since opportunity recognition (Baron 2006; Drucker 1998; Shane 2000), opportunity creation (Sarasvathy et al. 2003) and opportunity development (Sanz-Velasco 2006) make the heart of an entrepreneurial process, the study strategy here was based on the consideration of real life problems as new opportunities. The study process ensured the participation of the students in all the stages of problem-based learning (Ramsay and Sorrell 2007) providing activities which take place in a real enterprise (Ofsted 2004; Hynes 1996). The studies were realised according to the "Opportunity-oriented problem-based learning model for enhancing students' entrepreneurship" (Fig. 1).

This model was elaborated by the author and tried out within the European Social Fund project "Support to Education Research" in five schools of Latvia in 2012-2013

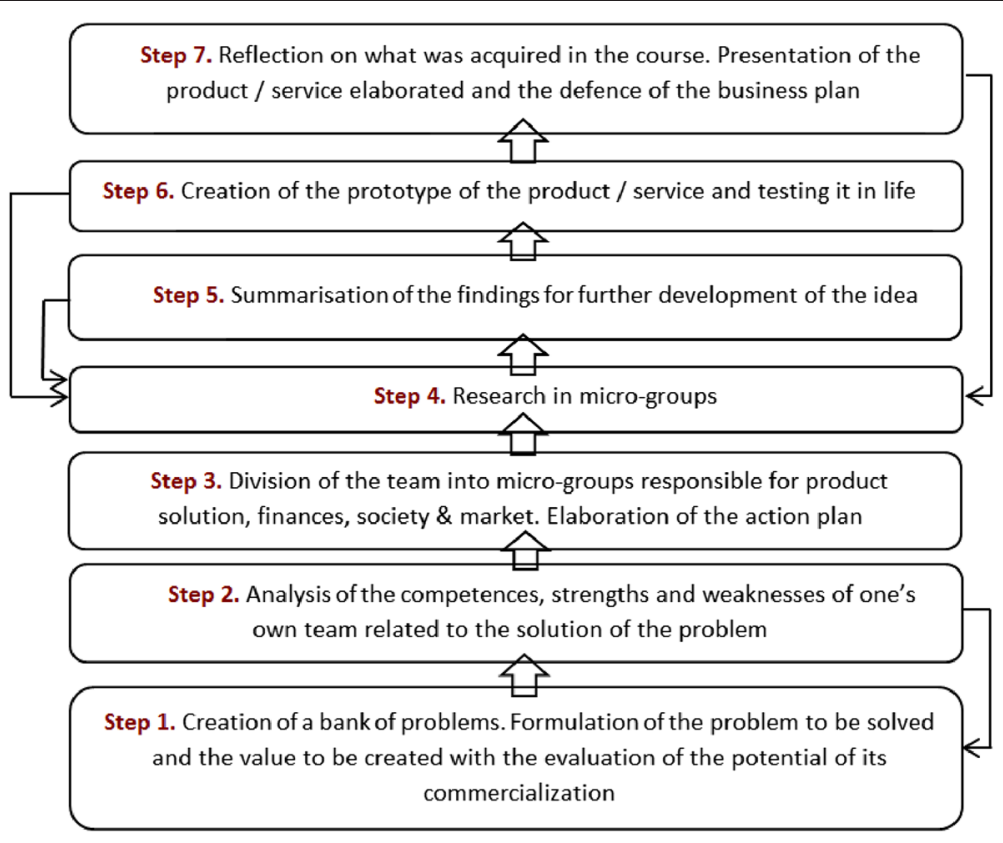

Fig. 1 Opportunity-oriented problem-based learning model for enhancing students' entrepreneurship 
(Oganisjana 2015); some elements of it were tested as well in three secondary schools of Malaysia within ASEM Asia-Europe Lifelong Learning Research HUB cooperation (Oganisjana et al. 2014;). Then it was adapted for university students, and as a teaching and learning strategy was tried out with second year bachelor students $(\mathrm{N}=85)$ in Riga Technical University (Oganisjana and Laizans 2015).

The students formed teams of 3-6 and started with the creation of a bank of problems of personal, social, cultural, environmental, economic and political character. Then each group discussed and decided which of the problems they would like to solve in order to create a new product or a service for commercialization. The groups had to realise each step depicted in the model (Fig. 1). By the end of the course they had created prototypes of new values and tried them out with potential customers. In the last lesson the groups presented their products or services-to-be and the business plans . Step 4 was connected to research and was of great importance as the groups had to come back to it after steps 5, 6 and 7 to conduct additional research in order to find some new opportunities for the perfection of the product or service-to-be and for the enhancement of its potential of commercialization (Fig. 1).

The study course "Economics of entrepreneurship" was realised by an interdisciplinary team of teachers-the author who was responsible for the delivering of the part of the course related to creative solutions of real life problems and elaboration of new products or services, and her colleague Talis Laizans - responsible for economic and financial aspects of entrepreneurship. The activities were organised in a democratic interactive manner. The theoretical part of the course was delivered in interactive lectures with active involvement of the students into discussions and activation of their minds related to the topics of the lectures making the students link them with their own experience. In the practical part of the course the students worked in small groups planning, managing, researching, analysing and discussing the results, reflecting, improving the ideas of the elaborated products or services and presenting them to the teachers, the other teams and invited entrepreneurs. They could always get their teachers and other specialists' consultation.

\section{Collaboration opportunities for university students in open innovation environment}

As open innovators learn by doing (Chesbrough et al. 2014), in order to promote university students' collaborative skills in open innovation environment, there should be several collaboration channels for making students learn by real doing, co-creating and using the opportunities to exchange knowledge and experience in multiple ways. It is in line with the standpoint that in the learning for entrepreneurship there should be frequent and planned work with entrepreneurs and other specialists from different fields (Hannon 2006; Hjorth and Johannisson 2007; Jones 2006; Wing Yan Man 2006).

So, to promote students' collaborative skills they should be provided with the opportunity to collaborate and to learn by collaborating, similarly as stated by Aristotle in his Nicomachean Ethics in 350 B.C.E: "For the things we have to learn before we can do them, we learn by doing them, e.g. men become builders by building and lyre players by playing the lyre; so too we become just by doing just acts, temperate by doing temperate acts, brave by doing brave acts" (Aristotle 350 B.C.E).

For making students' collaboration possible, the study ethos and atmosphere in entrepreneurship and innovation promoting education should be social, democratic, flexible 
and inspiring; students should be encouraged and motivated to cooperate (Fiet 2000; Heinonen and Poikkijoki 2006; Hjorth and Johannisson 2007; Kearney 1999; Löbler 2006; Taylor and Thorpe 2004). Such study atmosphere motivates students to be active, generative and inquisitive able to help themselves and others (Heinonen 2007; Politis 2005).

Trust is considered to be one of the challenges in the way of opening to partners and collaborating with them. It is argued that trust facilitates social interaction and provides basis for risk-taking and strengthens cooperation (Latusek-Jurczak and PrystupaRzadca 2014), facilitates flow of knowledge between partners developing a common language among them (Kirkman 2011). Collaboration occurs when individuals feel a sense of connectedness with their colleagues (Bresman et al. 1999) and are ready to share knowledge with them whom they perceive as trustworthy (Dirks and Ferrin 2001). According to Latusek-Jurczak and Prystupa-Rzadca (2014) trust is a product of repeated interaction; it is gained in time through mutual group member experience in collaboration and is supported by stable environmental and third parties. Therefore in the study course organised in Riga Technical University the trust building process was enabled by regular interaction at different levels, involving students, teachers and entrepreneurs both in face-to-face and online collaboration via the university ORTUS e-study portal.

One of powerful innovation promoting channels is cooperation between SMEs and higher education institutions. However, as shown by Chen et al. (2015) it often fails because of poor communication of SMEs with higher education institutions as "they do not acquire a clear understanding of the research progress and development, which brings up to uncertainty for the future and low confidence in the improvement to strength the enterprise technology through R\&D achievements, eventually leading to the abortion of the cooperation" (Chen et al. 2015:431).

The study course realized by the author and her colleague provided collaboration with three invited entrepreneurs who represent different fields of businesses. They shared their experience being ready to consult the students on any question they had. On the other hand, the students were offered to communicate with the entrepreneurs, inform them of their progress and identify a common platform for collaboration and co-creation of joint new values. In the end of the course the entrepreneurs participated in the evaluation of the students' presentations and the prototypes of the products or services elaborated by them.

The students were offered one more channel for collaboration. If a group of students, having analysed their competences, strengths and weaknesses related to the solution of the problem (step 2 in Fig. 1) came to the conclusion that they needed assistance of a specialist from certain fields, they were allowed to take into their team one specialist from outside the University.

While discussing the strategy of the delivery of the study course "Economics of Entrepreneurship" before starting it, the author was sure that the students could be recommended to use one more collaboration channel which could stimulate the involvement of potential customers in the new product or service development process. This decision was conditioned by the viewpoint that customers' involvement is most effective at early stage of the new product development process (Carbonell et al. 2009) though this point of view was shown to be arguable owing to researches which revealed 
that users are limited by their current experience and capabilities (Jespersen 2011) and their input should be regarded as inspiration rather than innovative solutions (Magnusson 2009).

Taking into consideration these aspects and avoiding overload of students, the collaboration channel between students and potential customers for their involvement in the new product development was not actively recommended to the students in the beginning as the course was planned only for one semester and the students had to carry out too many activities which were principally new to them. Though, such collaboration was not prohibited. The potential customers were communicated with mainly in the end of the course in the stage of the testing of the prototypes of the new products but that did not have a regular character (step 6 Fig. 1).

Thus, the students had the opportunity to realise at least five channels of collaboration shown in Table 1.

However, the systematic observation of the students' work showed that they did not exploit all the channels of collaboration very actively or at all. The most active were "Intra-group" and "Students-teachers" channels of collaboration. As for the "Inter-group" collaboration, it didn't work very effectively. When each group was presenting their work in different stages of the course, the other groups were to listen to them and be critical friends or potential partners for identifying some principal gaps giving some valuable advice or recognizing some opportunities for networking and becoming a "partner-company". The practice showed that groups were concentrated mainly on their own problems and did not wish to listen to other groups' presentations very attentively and were not so eager to find a common platform for inter-group collaboration. In cases when a group offered some ideas, the presenters' group did not always demonstrate great interest in utilizing the ideas proposed.

In the beginning the collaboration channel "Students-entrepreneurs" had mainly one direction of operation - from the entrepreneurs to the students who used to listen to them with great interest and ask some questions concerning basically entrepreneurs'

Table 1 The channels of collaboration in the study course "Economics of entrepreneurship"

\begin{tabular}{|c|c|c|}
\hline & Collaboration channel & The character of collaboration \\
\hline 1. & Intra-group collaboration & $\begin{array}{l}\text { Within each group students divided responsibilities } \\
\text { for product solution, finances, society or market } \\
\text { research exchanging findings and discussing } \\
\text { further activities with their group-mates }\end{array}$ \\
\hline 2. & Students - teachers collaboration & $\begin{array}{l}\text { Teachers were open to discuss, consult and } \\
\text { facilitate students' learning both at individual } \\
\text { and group level }\end{array}$ \\
\hline 3. & Inter-group collaboration & $\begin{array}{l}\text { In the end of each intermediate phase groups } \\
\text { presented their work done and discussed the } \\
\text { challenges faced with the other groups of } \\
\text { students and the teachers who had to be } \\
\text { their critical friends and potential partners }\end{array}$ \\
\hline 4. & $\begin{array}{l}\text { Students-entrepreneurs-teachers collaboration } \\
\text { inside the University }\end{array}$ & $\begin{array}{l}\text { Entrepreneurs were invited to share their experience } \\
\text { and to answer students' questions helping them to } \\
\text { understand practical aspects of entrepreneurship as } \\
\text { well as elaborate joint projects }\end{array}$ \\
\hline 5. & $\begin{array}{l}\text { Intergenerational collaboration with specialists } \\
\text { from outside the University }\end{array}$ & $\begin{array}{l}\text { Each group could recruit one member from outside } \\
\text { the University when they realised that they needed } \\
\text { specific experience and knowledge they } \\
\text { didn't have }\end{array}$ \\
\hline
\end{tabular}


experience but not related to their own projects or co-creation of at least ideas of some joint products or services. Only by the end of the study course the idea of collaboration with Aivars Zhimants, one of the invited entrepreneurs who is the co-owner of "Pure Chocolate", one of the most prospering chocolate production companies of Latvia, occurred to one of the groups. The group consisting of five female students had elaborated a gift set "Say 'Yes!' to the dress!" for little girls; that was meant for teaching them to sew dresses, using different models and decoration elements. The set was supposed to provide families and kindergartens with the opportunity to organise the child's socialization and development in a capturing manner while co-creating new dresses for dolls with mums, grannies and friends. The students decided to provide their gift set with a certain type of "Pure" chocolate, thus making their product a perfect gift to little girls.

Though the students were encouraged to cooperate with people of their parents and grandparents' generations also from outside the University filling up the gap of specific experience and knowledge which they lacked, they did not use this opportunity though in their reflections they highly appreciated such collaboration.

\section{Methods}

The first research question on how to promote university students' collaborative skills in open innovation environment was explored based on the scientific literature analysis and the systematic and systemic implementation of the steps of the "Opportunity-oriented problem-based learning model for enhancing students' entrepreneurship" in practice accompanying that with constant observation of the character and progress of students' cooperation with: each other, teachers and invited entrepreneurs.

The second research question was about what the students considered to be valuable in the study process organised in an open innovation environment.

Data collection was based on students' reflections; they had to answer the questions on what they considered to be of value in the open innovation environment and intergenerational collaboration with people from outside the formal University study framework. The questions were sent to the students in Google Drive electronic questionnaire forms.

Data analysis: before starting the qualitative content analysis, the reflection texts were read a number of times for achieving the deep understanding of the context as a whole and the meanings of the text fragments as recommended in the scientific literature on qualitative research (Cropley 2002; McTavish and Pirro 1990). The first trials of coding were carried out with tentative conceptual codes (Huber and Gürtler 2004; Strauss and Corbin 1990). Then the qualitative content analysis was conducted with open coding according to the "Step model of inductive category development" (Mayring 2000). The choice of this approach for the qualitative content analysis was conditioned by the author's experience of working with the model while conducting her $\mathrm{PhD}$ research "The development of students' enterprise in the study process" (Oganisjana 2010:42-45) and the opportunity to understand its essence in professor Philipp Mayring's lectures delivered in the University of Latvia. In the beginning the criterion of category definition was formulated derived from the theoretical background and the research question. Then in the course of the analysis of the text, categories were formulated inductively step by step, conducting the subsumption of old categories or formulating new ones. Having passed 10 and $50 \%$ of the material the categories were revised within a feedback loop to ensure the formative check of the reliability (Mayring 2000). 
Having worked through the texts, the categories were revised again and eventually reduced to the main categories and checked in respect to their reliability. This analysis resulted in thirteen categories: experience, knowledge, advice, problem solving, new ideas, other view of life, creativity, inspiration \& motivation, critical thinking, creation, support, intergenerational awareness and new opportunities (Table 3). That means that in the students' opinion intergenerational collaboration could provide a broad range of inflow and outflow opportunities related to these categories.

Interpretation of the results: this final stage had quantitative character in the end as the frequencies of the main categories were analysed.

This research had its peculiarities. The students were offered to answer the question "What to your mind can you acquire from representatives of other generations and give to them in the process of the co-creation of new values for commercialization?" Depending on the meanings of the answers they were systemized into three characteristic groups as some of them focused on what the students could get from that collaboration, the second group-on what they could give to representatives of other generations and the third group-on what could be exchanged via that collaboration channel.

For this reason it was decided to assign special labels to the categories developed in the course of the qualitative content analysis taking into account the three possible directions of action mentioned for the potential intergenerational collaboration:

- "in" (inflow) when the students were speaking about getting some useful ideas or help from potential collaboration partners related to the category spoken about;

- "out" (outflow) when the students were judging about being useful themselves to their potential collaboration partners related to the category spoken about;

- "in-out-in" when the students meant exchange of useful ideas or assistance with their potential collaboration partners related to the category spoken about (Table 2).

Table 2 A fragment of the qualitative content analysis and labelling of the categories

\begin{tabular}{|c|c|c|c|c|c|}
\hline & \multirow{2}{*}{$\begin{array}{l}\text { Students' opinions on what they could get and } \\
\text { share in the intergenerational collaboration in } \\
\text { the open study environment }\end{array}$} & \multirow[t]{2}{*}{$\begin{array}{l}\text { Categories spoken } \\
\text { about }\end{array}$} & \multicolumn{3}{|c|}{$\begin{array}{l}\text { The direction of interactions } \\
\text { and frequencies of categories }\end{array}$} \\
\hline & & & $\ln$ & Out & In-out-in \\
\hline \multirow[t]{5}{*}{ Student 1} & \multirow{5}{*}{$\begin{array}{l}\text { Of course I can get some new knowledge } \\
\text { (knowledge-in), a bit of their experience } \\
\text { (experience-in) and support (support-in). } \\
\text { From me they could get the understanding } \\
\text { of young people's ways of thinking (other } \\
\text { view of life) and problems which are topical } \\
\text { for us (intergenerational awareness - out). }\end{array}$} & Knowledge & 1 & & \\
\hline & & Experience & 1 & & \\
\hline & & Support & 1 & & \\
\hline & & Other view of life & & 1 & \\
\hline & & $\begin{array}{l}\text { Intergenerational } \\
\text { awareness }\end{array}$ & & 1 & \\
\hline \multirow[t]{4}{*}{ Student 2} & \multirow{4}{*}{$\begin{array}{l}\text { Perhaps we could try to solve the problem } \\
\text { together (problem solving-in-out-in). It could } \\
\text { be very useful as people of different generations } \\
\text { see things in different ways (other view of } \\
\text { life-in-out-in). We could exchange experience } \\
\text { (experience_in-out-in). I could provide fresh } \\
\text { ideas! (new ideas_out). }\end{array}$} & Problem solving & & & 1 \\
\hline & & Other view of life & & & 1 \\
\hline & & Experience & & & 1 \\
\hline & & New ideas & & 1 & \\
\hline \multirow[t]{2}{*}{ Student 3} & \multirow{2}{*}{$\begin{array}{l}\text { They have experience (experience-in) and } \\
\text { I_great enthusiasm and motivation to do } \\
\text { something valuable (inspiration \& } \\
\text { motivation_out) }\end{array}$} & Experience & 1 & & \\
\hline & & Inspiration \& motivation & & 1 & \\
\hline
\end{tabular}

Source: the author and the texts of students' reflections 
From the research point of view it is important to emphasize that the labelling of the categories required passing through the whole process of the qualitative content analysis one more time as the categories (which had already been developed in the qualitative content analysis according to "Step model of inductive category development") had to be reconsidered in light of the direction of operation of the category mentioned by the students. This was a new approach which the author had to apply to solve the situation in order to avoid the mixing up of the categories which were spoken about in different contexts and for opposite directions of their operation.

Table 2 illustrates a fragment for showing in what way the final stage of the qualitative content analysis was conducted combined with the labelling of the categories. For giving a better insight into the approach, the coding of the text fragments of students 1 and 2 (Table 2) will be considered in detail one sentence after another.

\section{Student 1}

Sentence 1: "Of course I can get some new knowledge a bit of their experience and support" concerns three categories 'knowledge, 'experience' and 'support'. All these three categories are labelled 'in' as the student is speaking about getting them (inflow).

Sentence 2: "From me they could get the understanding of young people's ways of thinking and problems which are topical for us. The first part of the sentence "From me they could get the understanding of young people's ways of thinking" is about 'other view of life' which the student thinks he/she could provide to representatives of other generations. The meaning of the entire sentence is about giving insight into the way of thinking and problems of one's own generation to people of other generations; it is about providing 'intergenerational awareness'. Both categories: other view of life and intergenerational awareness were labelled 'out' as the student is speaking about sharing, giving out (outflow).

Thus, for student 1 these five categories: knowledge, experience, support, other view of life and intergenerational awareness were written into the corresponding third column of Table 2 .

As the frequency of a category shows how many times ideas related to that category were mentioned in the text fragment, obviously the frequencies of each of the five categories were 1 , as in the text fragment of student 1 each of the category was spoken about only one time. Therefore in the last column "The direction of interactions and frequencies of categories" of Table 2 each of the first three categories: knowledge, experience, support got their frequencies 1 in the sub column with the label 'In', while the two other categories: other view of life and intergenerational awareness got their frequencies 1 correspondingly in the sub column with label 'Out'.

\section{Student 2}

Sentence 1: "Perhaps we could try to solve the problem together" corresponds to 'problem solving'; the word together means collaboration and exchange 
(inflow-outflow). Therefore the category 'problem solving' for this sentence was labelled 'in-out-in'.

Sentence 2: "It could be very useful as people of different generations see things in different ways" corresponds to the category 'other view of life', the labelling remains the same 'in-out-in' as the context of the second sentence hasn't changed compared with the first sentence.

Sentence 3: "We could exchange experience" corresponds to the category

'experience'; the labelling obviously is 'in-out-in'.

Sentence 4: "I could provide fresh ideas!" corresponds to the category 'new ideas,

but the labelling of this sentence is 'out' as here the student is speaking about sharing, giving out new ideas (outflow).

Thus, in the case of student 2 these four categories: problem solving, other view of life, experience and new ideas were written into the corresponding box of the third column of Table 2. The first three categories got their frequencies 1 in the sub column with the label 'In-out-in' while the last category got its frequency 1 correspondingly in the sub column with the label 'Out'.

Working in this way with the texts of the 85 students all the categories which emerged in each text fragment were written in column 3 and their frequencies - in the last column under the corresponding sub column 'In', 'Out' or 'In-out-in'. Having summed up all the frequencies of each category under the three labels 'In', 'Out' and 'In-out-in', Table 3 was made.

It shows that to the students' mind their collaboration via the intergenerational channel could be even richer and more multiple than the "exchange of knowledge across boundaries" discussed in scientific literature on open innovation (Chesbrough et al. 2014; Faludi 2014; Salter et al. 2014; Wikhamn 2013). The students considered that along with the exchange of knowledge and experience with people of other generations

Table $\mathbf{3}$ The frequency table of categories

\begin{tabular}{lllll}
\hline & Categories & \multicolumn{3}{l}{ Frequencies of the categories } \\
\cline { 3 - 5 } & & In & Out & In-out-in \\
\hline 1. & Experience & 38 & 15 & 10 \\
2. & Knowledge & 22 & 10 & 4 \\
3. & Advice & 7 & 5 & 2 \\
4. & Problem solving & 7 & 3 & 0 \\
5. & New ideas & 8 & 17 & 4 \\
6. & Other view of life & 9 & 8 & 1 \\
7. & Creativity & 2 & 4 & 0 \\
8. & Inspiration \& motivation & 3 & 7 & 2 \\
9. & Critical thinking & 4 & 1 & 1 \\
10. & Creation & 4 & 6 & 4 \\
11. & Support & 4 & 0 & 0 \\
12. & Intergenerational awareness & 2 & 6 & 1 \\
13. & New opportunities & 6 & 2 & 30 \\
\hline
\end{tabular}


and professions, they could give advice to each other, solve problems together, generate new ideas, shape other view of life, develop intergenerational awareness, etc.

However, aiming to get a more clear insight into the students' vision of the proportion of possible inflow and outflow via intergenerational collaboration channel, Table 3 was modified by adding the frequency of each category labelled as 'In-out-in' (the last sub column of Table 3) to the frequencies of the same category labelled both "In" and "Out" (Table 3). The logic of such an operation is the following: 'in-out-in' means exchange, which is both getting ('in', inflow) and giving ('out', outflow). Indeed, e.g., if the students in their reflections mentioned the exchange ('In-out-in') of experience 10 times (see the frequencies of the category 'Experience' in Table 3), it means they mentioned getting experience 10 times ('in') and sharing experience 10 times ('Out'). Therefore, the total frequency of the category 'Experience' labelled 'in' was reconsidered as $38+10$ (48); with the same logic the total frequency of the category 'Experience' labelled 'out' was reconsidered as 15 +10 (25). Having conducted analogical operations with the rest of the categories, Table 3 was modified into Table 4 which contains only two columns of category frequencies: 'in' and 'out'; these frequencies were named total frequencies.

Column "In" of Table 4 shows that the students consider that they could get mainly the opportunity of acquisition of new knowledge $(n=48)$ and experience $(n=26)$ from intergenerational collaboration. Though the rest of the categories were not spoken about so frequently, they should not be considered to be less important as they are related to two important domains:

- problem solving (7) which is related to getting advice $(n=9)$, critical thinking $(n=5)$, support $(n=4)$ and intergenerational awareness $(n=3)$;

- creation $(\mathrm{n}=8)$ which is conditioned by creativity $(\mathrm{n}=2)$, new ideas $(\mathrm{n}=12)$, new opportunities $(n=7)$, other view of life $(n=10)$ and inspiration \& motivation $(n=5)$.

Table 4 The table of total frequencies of categories

\begin{tabular}{llll}
\hline & Categories & \multicolumn{2}{l}{ Total frequencies of the categories } \\
\cline { 3 - 4 } \cline { 3 - 3 } 1. & Experience & 48 & Out \\
2. & Knowledge & 26 & 25 \\
3. & Advice & 9 & 14 \\
4. & Problem solving & 7 & 7 \\
5. & New ideas & 12 & 3 \\
6. & Other view of life & 10 & 21 \\
7. & Creativity & 2 & 9 \\
8. & Inspiration \& motivation & 5 & 4 \\
9. & Critical thinking & 5 & 9 \\
10. & Creation & 8 & 2 \\
11. & Support & 4 & 0 \\
12. & Intergenerational awareness & 3 & 7 \\
13. & New opportunities & 7 & 3 \\
\hline
\end{tabular}


As for the students' vision of the proportion of possible inflow and outflow via intergenerational collaboration channel, for illustration purposes Fig. 2 was constructed based on the total frequencies of the categories from Table 4.

The diagram in Fig. 2 displays that the students think that in the course of broad range collaboration with people of other generations who represent different fields, they could more give than get: new ideas, creativity, inspiration \& motivation as well as awareness of specific elements about their generation. Meanwhile in the students' opinion they would more get than give experience, knowledge, advice, problem solving, critical thinking, support and new opportunities from representatives of other generations while crossing the formal frames of university studies. There are two categories: other view of life and creation which were considered to be exchanged almost in equal proportions in the intergenerational collaboration. However, none of the students spoke about supporting representatives of other generations.

In the stage of the interpretation of the results, the author took into account as well her own observations which she had made in a special register in order to match students' opinions and perceptions of the reality with what she saw in the course of her work with them.

\section{Results and discussion}

The research showed that although the students were encouraged to act in an open environment with the opportunity to exploit different channels for collaboration and co-creation:

- they showed disposition to act mainly within small close circle of participants with their groupmates and teachers;

- the groups were not very open to the intergroup collaboration;

- the students appreciated the guest entrepreneurs' visits as sources for entrepreneurial inspiration but they didn't exploit that channel of collaboration very effectively;

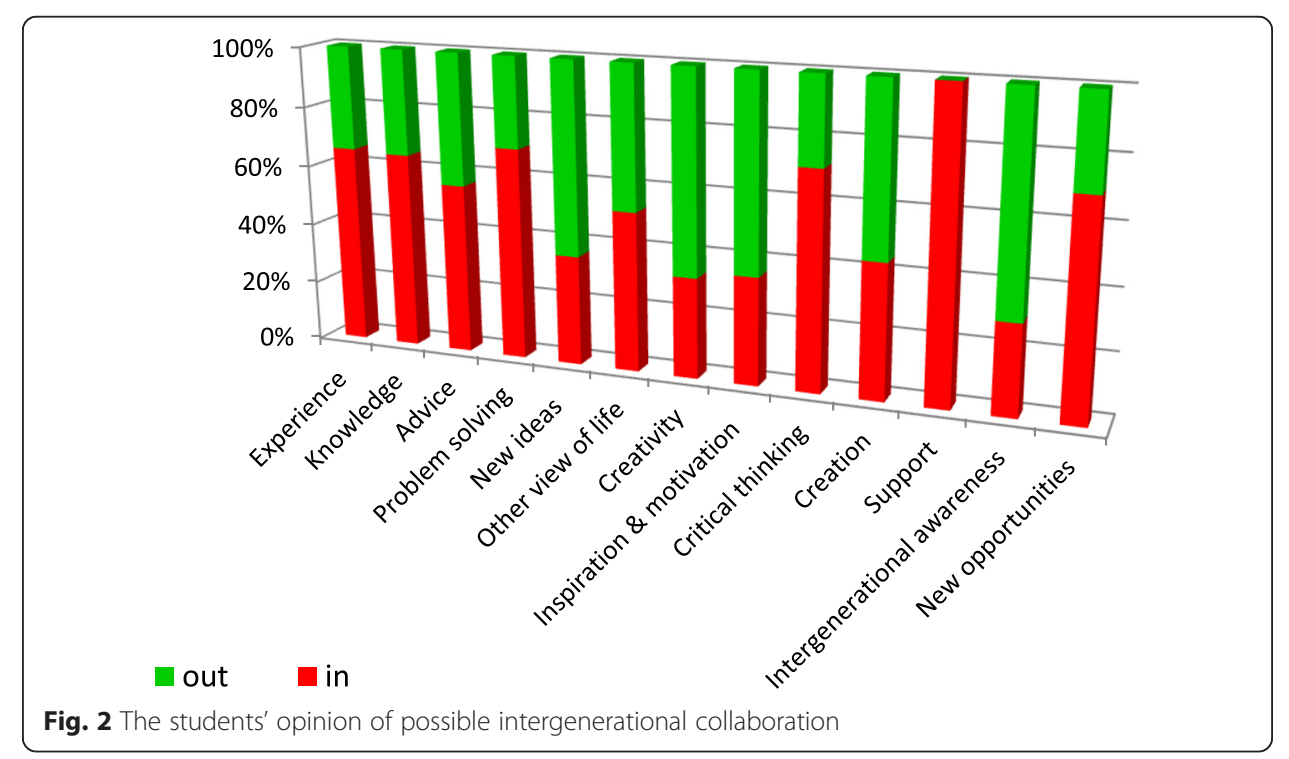


- the students lacked initiative and openness to the collaboration with people from outside the formal University study frames though, as the final defence of their projects revealed, they were aware that they needed specific experience and knowledge which they didn't have or lacked. So, their positive judgements about the advantages of intergenerational collaboration were not followed by corresponding behaviour in practice.

Thus, the students didn't use the potential of studying in open innovation environment to the full extent.

The analysis of the students' judgements showed that they were aware of the worth of studying in the open innovation environment and the potential collaboration with people who represent different generations and specializations. They mentioned that they would get not only knowledge and experience from entrepreneurs and specialists of different fields but also the opportunity to solve their own problems (get advice, critical view, support and intergenerational awareness) and creation of new things (get new ideas, new opportunities, other view of life, inspiration \& motivation).

At the same time the students were of the opinion that also they could be helpful to entrepreneurs and specialists of different fields related to twelve categories out of thirteen (Tables 3 and 4). None of the students spoke of lending support via that channel of collaboration. This phenomenon should be researched separately to reveal its causes. However the students think that in the intergenerational collaboration the other side could get from them mainly their experience, new ideas, knowledge, opportunity of creation something together, creativity, inspiration and motivation as well as awareness of young people's needs and interests.

The findings mentioned above indicate the topicality of conducting another research for finding out whether the students' passivity to exploit the open innovation environment is related to: a) lack of trust to other people or their knowledge; b) absence or lack of collaborative experience; c) peculiarities of the culture of individualism; d) lack of self-confidence or shyness to make the first step to others; e) laziness to undertake additional activities outside the traditional university study frames; f) conservative thinking and stereotypes of expectations from the organisation of the study process in higher education institutions which traditionally is perceived as lecturing, reading study materials, solving problems from books and passing exams; g) closedness or lack of openness to novelty; h) lack of the sense of connectedness; i) underdeveloped communication skills; or to some other causes. Such a research will enable to improve the content, philosophy, strategy and methods of the delivery of not only this study course but also any other study course in the university in open innovation environment.

This study showed very clearly that researchers should be especially alert related to the situations when respondents are speaking about values. Merely judging about what is worth doing does not guarantee that people will act according to these values. There may be a very big gap between words and actions.

The limitation of this research could be conditioned by the traditions of qualitative research which welcome the conducting of qualitative content analysis in a group of two-three researchers. This is a special measure which is to ensure high validity and reliability of the qualitative content analysis as in the course of coding of the text fragments, their meanings should be discussed by the research team; only having come to a 
certain agreement, the most appropriate conceptual code or codes should be assigned. It is a very time-consuming procedure which is a real challenge for two or three researchers to find time and gather together for several hours to discuss each fragment of the text. For this reason the author had to conduct the qualitative content analysis alone based on her 8-year-long experience in qualitative research taking theory-based measures for ensuring the validity and reliability of the research.

In the beginning of the research it was shown that the promotion of students' collaborative skills is possible when they participate in collaboration. Thus, the main indicator of the promotion of students' collaborative skills was assumed to be their participation in collaboration. However in the future researches it is feasible to explore the impact of students' participation in open innovation environment on their collaborative skills from the mixed qualitative and quantitative research perspective.

\section{Conclusions}

It was the author's first experience to deliver the study course on entrepreneurship trying to make the students "be in entrepreneurs' shoes". The research conducted along with the delivery of the study course has disclosed and put forward a number of problems for further researches.

The main conclusion made here is formulated as a hypothesis:

University students' collaborative skills could be promoted effectively if multi-channel collaboration in open innovation environment becomes a habitual feature and culture of the University study process across a broad range of contexts versus discrete campaigns of cultivating openness within a separate study discipline.

\footnotetext{
Author's information

Doctor of pedagogy Karine Oganisjana is an associate professor in the Faculty of Engineering Economics and Management of Riga Technical University. Her scientific and pedagogical interests encompass the development and research of entrepreneurship, innovation, social innovation, creativity, analytical and critical thinking, interdisciplinary and cross-cultural research, qualitative research and elaboration of modern teaching and learning materials and methods for learners of different ages.
}

\section{Acknowledgement}

The paper was supported by the National Research Program 5.2. "Economic Transformation, Smart Growth, Governance and Legal Framework for the State and Society for Sustainable Development - a New Approach to the Creation of a Sustainable Learning Community (EKOSOC-LV)" and conducted within the project 5.2.7 "Involvement of the society in social innovation for providing sustainable development of Latvia".

Received: 9 September 2015 Accepted: 26 November 2015

Published online: 01 December 2015

References

Antonites AJ, Van Vuuren JJ. Inducing entrepreneurial creativity, innovation and opportunity - finding skills. SAJEMS NS. 2005;8(3):255-71.

Aristotle. Nicomachean Ethics. Book II. Translated by W. D. Ross. Written 350 B.C.E. Available at http://classics.mit.edu/ Aristotle/nicomachaen.2.ii.html.

Baron RA. Opportunity recognition as pattern recognition: how entrepreneurs "connect the dots" to identify new business opportunities. Acad Manage Perspect. 2006;20(1):104-19.

Barrick MR, Mount MK. The big five personality dimensions and job performance: a meta-analysis. Pers Psychol. 1991;44(1):1-26.

Bikse V. Research "The progress of entrepreneurship education in Latvia after joining the European Union" (Pêtijums "Latvijas progress uznēmējdarbibas izglïtibas attīstïba pēc iestäjas Eiropas Savienïba"). Riga: University of Latvia, Faculty of Economics and Management, European Commission Representation in Latvia; 2009. Available at http://providus. Iv/article_files/1268/original/Bikse_EK_Petijums_09.pdf?1328195157.

Bresman H, Birkinshaw J, Nobel R. Knowledge transfers and international acquisitions. J Int Bus Stud. 1999;30(3):349-462

Caird SP. What do psychological tests suggest about entrepreneurs? J Managerial Psychol. 1993;8(6):11-20.

Carbonell P, Roriguez-Escudero Al, Pujari D. Customer involvement in new service development: an examination of antecedents and outcomes. J Prod Innov Manage. 2009;26:536-50.

Chen F, Wu C, Yang W, Zhang W. S\&T collaboration platform for higher education institutions and industry: a case study of Wenzhou, China. Eng Econ. 2015;24(5):424-36. 
Chesbrough HW. Open innovation: the new imperative for creating and profiting from technology. MA: Harvard Business Press; 2003.

Chesbrough HW, Kim S, Agogino A. Chez Panisse: Building an open innovation ecosystem. University of California Berkeley. 2014;56(4):144-71.

Comings DE, Gonzalez N, Wu S, Gade R, Muhleman D, Saucier G, et al. Studies of the 48 bp repeat polymorphism of the DRD4 gene in impulsive, compulsive, and addictive behaviors: Tourette syndrome, ADHD, pathological gambling, and substance abuse. Am J Med Genet. 1999;88(4):358-68.

Cropley A. Qualitative research methods: An introduction for students of psychology and education. Rīga: Zinātne; 2002.

Dirks KT, Ferrin DL. The role of trust in organizational setting. Organ Sci. 2001;12(4):450-69.

Drucker PF. The discipline of innovation. Harv Bus Rev. 1998:80(8):95-102.

Erkkila K. Enterprise education in the case of Finland. Sydney: Presented at the World Congress of Comparative Education Societies; 1996.

Faludi J. Fifty shades of innovation: from open toward user, and open collaborative forms of innovation-an overview. Budapest Manage Rev. 2014;45(11):33-43.

Fiet JO. The pedagogical side of entrepreneurship theory. J Bus Ventur. 2000;16(2):101-17.

Gibb AA. Creating conducive environments for learning and entrepreneurship: living with, dealing with, creating and enjoying uncertainty and complexity. Ind Higher Educ. 2002;19(3):135-48.

Hannon PD. Teaching pigeons to dance: sense and meaning in entrepreneurship education. Educ Train. 2006;48(5):296-308

Hannon PD, Collins LA, Smith AJ. Exploring graduate entrepreneurship: a collaborative, co-learning based approach for students, entrepreneurs and educators. Ind Higher Educ. 2005;19(1):11-24.

Heinonen J. An entrepreneurial-directed approach to teaching corporate entrepreneurship at university level. Educ Train. 2007:49(4):310-24

Heinonen J, Poikkijoki SA. An entrepreneurial-directed approach to entrepreneurship education: mission impossible? J Manage Dev. 2006;25(1):80-94.

Hjorth D, Johannisson B. Learning as an entrepreneurial process. In: Fayolle A, editor. Handbook of research in entrepreneurship education, vol. 1. Cheltenham: Edward Elgar Publishing; 2007. p. 46-67.

Huber G, Gürtler L. AQUAD 6. Manual for the analysis of qualitative data. Tübingen: Ingeborg Huber Verlag; 2004.

Hynes B. Entrepreneurship education and training - introducing entrepreneurship into non-business disciplines. J Eur Ind Train. 1996;20(8):10-7.

Jespersen KR. Online channels and innovation: are users being empowered and involved? Int J Innov Manage. 2011;15(6):1141-59.

Jones C. Constructive alignment: a journey for new eyes. J Enterprising Cult. 2006;14(4):291-306.

Kearney P. Enterprising ways to teach \& learn. Book 1: enterprise principles. West Hobart Tasmania: Enterprise Design Associates Pty Ltd; 1999.

Kirkman DM. Knowledge management strategies in an open innovation environment. Proc Acad Strateg Manage. 2011;10(1):53-9.

Latusek-Jurczak D, Prystupa-Rzadca K. Collaboration and trust-building in open innovation community. J Econ Manage. 2014;17:48-62.

Löbler H. Learning entrepreneurship from a constructivist perspective. Technol Anal Strateg Manage. 2006;18(1):19-38.

Magnusson PR. Exploring the contributions of involving ordinary users in ideation to technology-based services. J Prod Innov Manage. 2009;26:578-93.

Mayring P. Qualitative content analysis. Forum: Qualitative Social Research, 2000;1(2). Available at http://www.utsc. utoronto.ca/ kmacd/IDSC10/Readings/text\%20analysis/CA.pdf.

McMullan W, Long W. Entrepreneurship education in the nineties. J Bus Venturing. 1987;2(3):261-75.

McTavish D, Pirro E. Contextual content analysis. Qual Quant. 1990;24:245-65.

Ofsted. Learning to be enterprising: An evaluation of enterprise learning at Key Stage 4. Gov. UK Document reference number: HMI 2148; August, 2004. Available at http://www.readyunlimited.com/wp-content/uploads/2015/09/Learningto-be-enterprising-an-evaluation-of-enterprise-learning-KS4.pdf.

Oganisjana K. Interdisciplinary teaching and learning for promoting entrepreneurship (The results of the ESF project "Support to Education Research". Riga: University of Latvia; 2015. Available at https://www.lu.lv/fileadmin/user_ upload/lu_portal/2013/esf/petijumiem/kompetence/3/nob/Karine_Oganisjana_zinojums_2015.pdf.

Oganisjana K. Studentu uzṇēmïbas veicināšana studiju procesā (The development of students' enterprise in the study process). PhD thesis. University of Latvia, 2010. Available at https://uis.lu.lv/pls/pub/luj.fprnt?|=1\&fn=F1648681065/ Karine\%200ganisjana\%202010.pdf

Oganisjana K, Laizans T. Opportunity-oriented problem-based learning for enhancing entrepreneurship of university students. Presented in the 20th International Scientific Conference Economics and Management (ICEM). Lithuania: Kaunas University of Technology; 2015.

Oganisjana K, Koke T, Rahman S, Fernate A, Rutka L. The development of entrepreneurship in interdisciplinary study environment: first achievements, hindrances and perspectives. Int J Bus Soc. 2014;15(3):447-64.

Politis D. The process of entrepreneurial learning: a conceptual framework. Entrep Theory Pract. 2005;29(4):399-424.

Rae D. Connecting enterprise and graduate employability. Challenges to the higher education culture and curriculum? Educ Train. 2007:49(8/9):605-19.

Rae D, Carswell M. Using a life-story approach in researching entrepreneurial learning: the development of a conceptual model and its implications in the design of learning experiences. Educ Train. 2000:42(4/5):220-7.

Ramsay J, Sorrell E. Problem-based learning: an adult-education-oriented training approach for SH\&E practitioners. Prof Saf. 2007;52(9):41-6.

Salter A, Crscuolo P, Ter Wal ALJ. Coping with open innovation: responding to the challenges of external engagement in R\&D. Calif Manage Rev. 2014;56(2):77-94.

Sanz-Velasco SA. Opportunity development as a learning process for entrepreneurs. Int J Entrep Behav Res. 2006;12(5):251-71.

Sarasvathy S, Dew N, Venkataraman S. Three views of entrepreneurial opportunity. In: Acs Z, Audretsch D, editors. Handbook of entrepreneurship research. Dordrecht: Kluwer Academic Publishers; 2003. p. 141-60. 
Shacklock G, Hattam R, Smyth J. Enterprise education and teachers' work: exploring the links. J Educ Work. 2000;13(1):41-60.

Shane S. Prior knowledge and the discovery of entrepreneurial opportunities. Organ Sci. 2000;11(4):448-69.

Shane S, Nicolaou N, Cherkas L, Spector TD. Do openness to experience and recognizing opportunities have the same genetic source? Hum Resour Manage. 2010;49(2):291-303.

Sogunro OA. Efficacy of role-playing pedagogy in training leaders: some reflections. J Manage Dev. 2004;23(4):355-71.

Strauss A, Corbin J. Basics of qualitative research: grounded theory procedures and techniques. Newbury Park: Sage; 1990.

Tan SS, Frank Ng CK. A problem-based learning approach to entrepreneurship education. Educ Train. 2006;48(6):416-28. Taylor DW, Thorpe R. Entrepreneurial learning: a process of co-participation. J Small Bus Enterp Dev. 2004;11(2):203-11.

Timmons JA, Stevenson HH. Entrepreneurship education in the 1980s - what entrepreneurs say. In: Kao J, Stevenson $\mathrm{HH}$, editors. Entrepreneurship - what it is and how to teach it. Cambridge: Harvard Business School Press; 1985. p. $115-34$.

Wikhamn BR. Two different perspectives on open innovation - libre versus control. Creativity Innov Manage. 2013;22(4):375-89.

Wilson K. Entrepreneurship education in Europe. In: Potter J, editor. Entrepreneurship and Higher Education: OECD; 2008. p. 119-138.

Wing Yan Man T. Exploring the behavioural patterns of entrepreneurial learning. A competency approach. Educ Train. 2006:48(5):309-21.

Yun JJ. How do we conquer the growth limits of capitalism? Schumpeterian Dynamics of Open Innovation. J Open Innov Technol Market Complexity. 2015;1(1):1-20.

Submit your manuscript to a SpringerOpen ${ }^{\circ}$ journal and benefit from:

- Convenient online submission

- Rigorous peer review

- Immediate publication on acceptance

- Open access: articles freely available online

- High visibility within the field

- Retaining the copyright to your article

Submit your next manuscript at $>$ springeropen.com 